\title{
A review of the taxonomy and systematics of aigialosaurs
}

\section{A.R. Dutchak}

Department of Geological Sciences, University of Colorado at Boulder, Boulder, Colorado 80309, USA. Email: dutchak@colorado.edu

Manuscript received: November 2004; accepted: January 2005

\begin{abstract}
Aigialosaurs have been recognised as a group of semi-aquatic marine reptiles for over one hundred years. While the taxonomic status of aigialosaurs has changed little in the past century, the interfamilial relationships have been modified considerably making the phylogenetic relationships between aigialosaurs, mosasaurs, dolichosaurs, coniasaurs, varanids and other squamates a topic of much debate. The monophyly of the family Aigialosauridae has been contested by recent studies and remains highly questionable. The higher-level relationships of mosasauroids within Squamata remain problematic with studies placing mosasauroids outside of Varanidae, Varanoidea and even Anguimorpha. These findings conflict with earlier views that aigialosaurs (and by association mosasaurs) were closely related to Varanus. This study concludes that further descriptions of aigialosaur taxa are needed, and several key flaws need to be addressed in the data matrices that have been used in previous studies. This should facilitate the clarification of aigialosaur systematic relationships both within Mosasauroidea and Squamata.
\end{abstract}

Keywords: aigialosaurs, mosasaurs, systematics, taxonomy

\section{Introduction}

The conventional characterisation of an 'aigialosaur' is that they are semi-aquatic squamates that lived in marginal marine habitats during the early stages of the Late Cretaceous. The first described aigialosaurs were found in the Cenomanianaged rocks along the coast of the Adriatic Sea; more recently, Bell (1997) reported on the presence, though without any description of the animal, of an aigialosaur from North America (this characterisation is now revised in the present volume). Recent taxonomic and systematic questions of aigialosaur nomenclature and phylogenetic relations have focused on which taxa are valid, who is their closest sister group within Squamata, and whether or not there is a monophyletic Aigialosauridae (Caldwell et al., 1995; Bell, 1997), all of which harkens back to a similar debate between Kornhuber (1873) and Kramberger (1892).

There are currently six published descriptions of putative aigialosaurs: Aigialosaurus dalmaticus Kramberger, 1892,
A. novaki Kramberger, 1892, Carsosaurus marchesetti Kornhuber, 1893, Opetiosaurus bucchichi Kornhuber, 1901, Proaigialosaurus hueni Kuhn, 1958 and Haasiasaurus gittelmani (Polcyn et al., 1999). In addition to the specimens properly described in the literature there are two more important taxa that have played integral roles in recent discussions of aigialosaur taxonomy and phylogeny. Dallasaurus turneri Bell \& Polcyn, 2005 (in previous literature as 'the Dallas aigialosaur' although the most recent systematic analysis places it as the sister group to clidastine mosasaurs) is described in the present volume, and 'the Trieste aigialosaur', erroneously referred to the genus Opetiosaurus (Calligaris 1988) and then left unnamed by Carroll \& DeBraga (1992) and later researchers, which is in the process of being described (A. Palci, pers. comm.). These eight specimens represent the complete dataset upon which our understanding of aigialosaurs is based.

It is the goal of this study to review the literature describing and interpreting these eight specimens from the first publication (Kramberger, 1892) through the most recent systematic 
analyses (Bell \& Polcyn, 2005; Polcyn \& Bell, 2005). This review will identify gaps in the current knowledge of aigialosaurs, and by association, weaknesses in current systematic hypotheses. By analysing the strengths and weaknesses of previous taxonomic and systematic interpretations it will be possible to determine the best starting points for future research and the directions that this research should take.

\section{Review}

The family Aigialosauridae was erected by Kramberger (1892) to contain the previously described Acteosaurus von Meyer, 1860 and Adriosaurus Seeley, 1881, his newly described specimens from the island of Lesina, Italy (now Hvar, Croatia) A. dalmaticus and $A$. novaki, and the renamed Pontosaurus (Hydrosaurus) lesinensis originally described in 1873 by Kornhuber (for a review of $P$. lesinensis and dolichosaur systematics see Pierce \& Caldwell, 2004). Kramberger grouped the Aigialosauridae with the Dolichosauridae (including only Dolichosaurus longicollis 0wen, 1850) in the new suborder 0phiosauria (Fig. 1a; this name was actually preoccupied and was emended to Dolichosauria at a later date). Kramberger hypothesised that the Aigialosauridae were ancestral to modern lacertilians, dolichosaurs, and pythonomorphs (snakes and mosasaurs).

Kramberger's classification scheme was reviewed by Kornhuber (1901), who determined that the members of the family Aigialosauridae did not differ significantly from extant monitors and thus did not merit removal from the family Varanidae. Kornhuber (1901) argued that the 'completely different shape' of the quadrate in A. dalmaticus was not sufficient cause to erect a new family, suggesting instead that quadrate shape was extremely variable across Varanidae and that the differences seen in A. dalmaticus were not exceptional. Kornhuber (1901) went on to point out that if any specimen were to be used to illustrate a transitional form between varanids and pythonomorphs it should be not Kramberger's A. dalmaticus, but instead his new specimen 0 . bucchichi based on its 'special, outstanding dentition' (the cone-shaped dentition of 0 . bucchichi appears to have been crushed, giving the teeth a more leaf-like appearance (A. Dutchak, pers. obs.). It should be noted that in addition to contradicting Kramberger's (1892) classification scheme, Kornhuber (1901) also refused to acknowledge the renaming of Pontosaurus, repeatedly referring to the specimen as Hydrosaurus throughout his paper.

With two totally different classification schemes in the literature, Nopcsa (1903) was the next to review the 'Varanuslike lizards of Istria'. While agreeing with Kramberger (1892) that the Aigialosauridae were sufficiently different from extant varanids to merit a familial distinction, Nopcsa (1903) proposed a different distribution of genera amongst the families. It was Nopcsa (1903) who recognised that the lengthy neck

\section{Suborder Dolichosauria}

$\begin{array}{ll}\text { Aigialosauridae } & \text { Dolichosauridae } \\ \text { Acteosaurus } & \text { Dolichosaurus } \\ \text { Adriosaurus } & \\ \text { Pontosaurus } & \\ \text { Aigialosaurus } & \end{array}$

$a$.

\section{Order Squamata}

\section{Suborder Lepidosauria}

$\begin{array}{ll}\text { Aigialosauridae } & \text { Dolichosauridae } \\ \text { Aigialosaurus } & \text { Dolichosaurus } \\ \text { Carsosaurus } & \text { Acteosaurus } \\ \text { Opetiosaurus } & \text { Pontosaurus } \\ \text { ?Mesoleptos } & \text { Adriosaurus }\end{array}$

b.

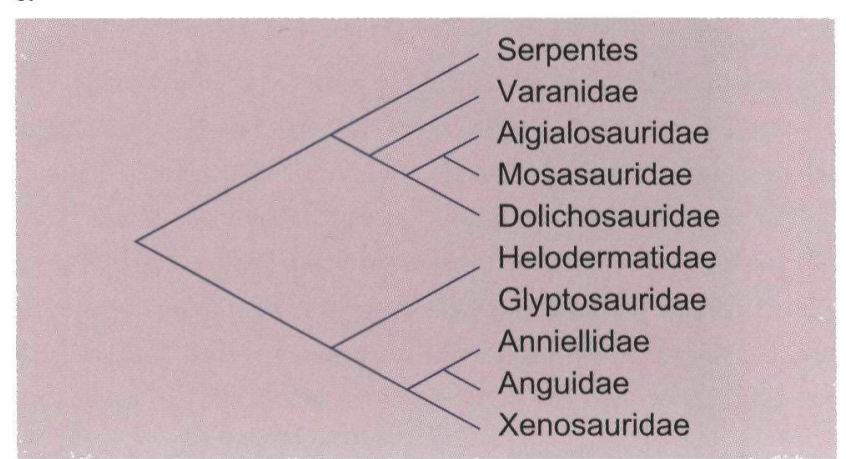

c.

Fig. 1. a. The original arrangement of aigialosaurs and dolichosaurs according to Kramberger (1892); b. the modified taxonomic scheme proposed by Nopcsa (1903) separating the long-necked dolichosaurs from the larger aigialosaurs; $c$. the systematic relations of anguimorph lizards, modified from Camp (1923).

and tail and reduced limbs of Acteosaurus, Adriosaurus and Pontosaurus were much more similar to characteristics seen in Dolichosaurus, thus meriting their placement in the family Dolichosauridae (Fig. 1b). The remaining lizards (Aigialosaurus, Carsosaurus, Opetiosaurus and Mesoleptos zendrini) were grouped together in an emended Aigialosauridae.

Nopcsa $(1908,1923)$ again reviewed the relationships of fossil lizards, with the latter paper being his final word on the subject. Rejecting his earlier (Nopcsa, 1903) suggestion that dolichosaurs and aigialosaurs were distantly related Nopcsa determined that they should be placed in the same family. After some taxonomic juggling (see Nopcsa, 1923 for details) the family Dolichosauridae was emended to include three subfamilies: Dolichosaurinae (Acteosaurus, Adriosaurus, Pontosaurus, Dolichosaurus and the newly named Eidolosaurus), 
Aigialosaurinae (Aigialosaurus, Carsosaurus and Opetiosaurus) and the newly erected, monogeneric Mesoleptinae (Mesoleptos). Nopcsa (1923) also went to great lengths to disagree with earlier arguments by Féjérváry (1918), who suggested that the cranial similarities seen in aigialosaurs and mosasaurs were a result of convergence, and to state that the subfamily Aigialosaurinae contained the ancestors of the mosasaurs. In addition to supporting the aigialosaur-mosasaur relationship, Nopcsa (1923) also suggested an aigialosaurian-like ancestor for snakes, based on similarities in the caudal regions of A. dalmaticus and Pachyophis woodwardi.

At the same time that Nopcsa (1923) was penning his final thoughts on the subject, Camp (1923) published his classification of lizards. His taxonomic groupings (Fig. 1c) were in general agreement with earlier works by Dollo (1904), Williston (1904) and Nopcsa (1923) although the details of the taxonomy varied slightly. The families Varanidae, Dolichosauridae and Aigialosauridae were grouped in the superfamily Varanoidea. Camp (1923) believed that aigialosaurs were descended from 'true lizards near the Varanidae' and that they were ancestral to both the mosasaurs and the dolichosaurs (Camp did not think snakes were dolichosaur descendants, instead placing Serpentes as a suborder derived from a common ancestor of aigialosaurs and varanids). The classification scheme devised by Camp (1923) was used by most researchers in the field as the working model until it was thoroughly revised by Estes et al. (1988) using computer-based parsimony methods.

The next to examine aigialosaurs were McDowell \& Bogert (1954) in their treatise on Lanthanotus borneensis. They concluded that $L$. borneensis was not a highly derived varanid but instead a relict aigialosaur. This claim was based on the similarities in the hinge of the lower jaw (while superficially similar, the hinges differ significantly upon closer examination), reduced phalangeal number (their count of four phalanges on the fourth digit of the aigialosaur pes has been shown to be erroneous; Opetiosaurus and Aigialosaurus both show five phalanges in this position), and shortened limbs seen in aigialosaurs and L. borneensis. McDowell \& Bogert (1954) placed Lanthanotus in a clade with dolichosaurs, aigialosaurs and mosasaurs but did not hypothesise any sister group relations within this clade.

After McDowell \& Bogert (1954) mentioned aigialosaurs, Kuhn (1958) described Proaigialosaurus hueni from skull fragments found at Solnhofen in southern Germany. The description is not very thorough and the specimen has since been lost. Thus Proaigialosaurus made an extremely brief, and not terribly useful, appearance in aigialosaur literature. Should the specimen ever be relocated, a thorough redescription and detailed drawings and photographs should serve to verify the original diagnosis and allow the specimen to be placed in a systematic context.

When Camp \& Allison (1961) revised the earlier classification of lizards (Camp, 1923) the general arrangement remained the same with two new families being added to the superfamily Varanoidea: the Helodermatidae and the Lanthanotidae (the authors obviously disagreed with the classification of Lanthanotus as an aigialosaur by McDowell and Bogert (1954)). Russell (1967) used Camp \& Allison's (1961) taxonomic scheme in his landmark publication which focused on the Mosasauridae but also mentioned basal mosasauroids. While discussing mosasaurian ancestors, Russell suggested that they likely passed through a body-form similar to that of aigialosaurs, reaffirming the close evolutionary relationship of the two groups. Russell also took issue with the suggestion by McDowell \& Bogert (1954) that Lanthanotus had its origin within the mosasauroids and instead placed them in a polytomy with helodermatids, varanids and 'saniwinines' as 'tertiary' grade lizards.

Russell (1967) covered the subject of mosasaurs so thoroughly that few new studies appeared on the subject, save various new species descriptions, for the following two decades. Aigialosaurs were left unmentioned in the literature during this period.

The year before Russell (1967) published his manuscript, in 1966, the first English translation of Hennig's (1966) 'Grundzüge einer Theorie der phylogenetischen Systematik' (Phylogenetic Systematics) appeared. While the method was set out in the 1950s, the use of Hennig's parsimony analysis of phylogeny did not become popular until personal computers became available to run large analyses. The first large squamate phylogeny to be analysed using computers was Estes et al. (1988). The paper was a first attempt to put all lizard families in a systematic context using both osteological and soft tissue characters. This study resulted in a sizeable departure from the classification of Camp (1923) on the familial level. Unfortunately, fossil squamates, such as mosasaurs, dolichosaurs and aigialosaurs, were not included in the analysis.

Despite being excluded from the Estes et al. (1988) analysis, aigialosaurs did reappear in the literature in the form of a survey of Adriatic lizards by Calligaris (1988). This review added little information to that already known from much earlier in the century with the exception of mentioning a new specimen from Komen, Slovenia. The new specimen was casually referred to the genus Opetiosaurus but was not formally described. The conclusions that Calligaris (1988) drew from his review were that the taxonomy proposed by Nopcsa (1903) was sufficient (Calligaris refers to Nopcsa (1923) instead of Camp (1923), who emended the familiar descriptions and whose classification scheme was more widely accepted) and that there was little to be done with the group until further specimens were discovered.

The following descriptive and interpretative studies are all cladistic studies of phylogeny, the data of which are all explicitly available for criticism in each publication. 


\section{Carroll \& DeBraga (1992)}

Carroll \& DeBraga (1992) published general descriptions of 0. bucchichi, A. dalmaticus and Calligaris' (1988) Komen specimen, which they referred to not as Opetiosaurus but instead as 'the Trieste aigialosaur'. Carroll \& DeBraga (1992) assumed that the three specimens were closely related and shared similar ways of life. This meant that they were describing a generalised 'aigialosaurian-grade' body-plan. Carroll \& DeBraga (1992) used the information from their descriptions to code a fifteen-character matrix for 'Aigialosauridae' (a composite of characters from the three specimens in the study, in effect an assumed monophyletic group) and nine other terminal taxa in an attempt to determine aigialosaur relationships within Anguimorpha. The resulting tree (the first published phylogenetic analysis to include aigialosaurs) placed aigialosaurs in a polytomy with the Lanthanotus/Varanus and Cherminotus/ Saniwa clades. This grouping was supported by several characters (the shape of the pterygopalatine suture, the degree of contact between the supraoccipital and the parietal, the presence or absence of a notched dentary, and the size of the supratemporal process of the parietal) of which only the latter two are visible on known aigialosaur specimens. It should be noted that, while the systematic analysis was relatively cursory by some standards, this study represents the first computergenerated systematic analysis of aigialosaur relationships.

\section{DeBraga \& Carroll (1993)}

DeBraga \& Carroll (1993) proceeded to publish a larger-scale analysis of mosasauroid and lizard systematics. Aigialosaurs were again coded as a single terminal taxon, negating any possibility of testing their monophyly. The analysis (142 characters and 17 taxa) was designed primarily to study the internal relationships of the family Mosasauridae but the Aigialosauridae were found to nest as the sister group to the Mosasauridae and the Varanidae were determined to be the sister group to the mosasauroids (aigialosaurs and mosasaurs). DeBraga \& Carroll (1993) concluded mosasauroids were descended from ancestral varanids and proposed 39 character shifts that had occurred in aigialosaurs following the speciation event that separated them from the lineage of modern varanids. Many of these characters were visible on only a single aigialosaur specimen and some of the characters for which state changes are described are not visible in any of the aigialosaur specimens (premaxillary tooth count, premaxillary bar length, ossified tympanum, anteromedial and posteromedial processes of the coronoid, and strength of coronoid/ prearticular suture). This lack of information and variation among character states within Aigialosauridae was not deemed to be a problem as they were assumed to represent a monophyletic assemblage.
DeBraga \& Carroll (1993) have received less attention than another data set produced around the same time (Bell, 1993; see below) due in part to the characters chosen by the authors. In many cases the characters are redundant, resulting in higher weighting of certain morphological changes, or vaguely worded (e.g., character 62: posteromedial process of coronoid tightly/weakly sutured to prearticular; the 'strength' or 'weakness' of a suture is impossible to interpret without quantifying the mobility of the elements involved). For example, DeBraga and Carroll's (1993) characters 1, 2, 6, 9, 17, and 21 are all associated with a lengthening of the snout region. Characters 24 and 25 both deal with the shape of the orbital margin of the frontal (25 is scored as straight versus concave and 26 as straight versus convex). These characters could easily be condensed into a single multi-state character. Both Globidens (strongly convex) and Plotosaurus (slightly concave) were scored for the shape of the frontal orbital margin when in both of these genera the frontal is excluded from the orbit by the prefrontal and postorbitofrontal (Bell, 1997). Numerous problems with character definition and weighting have led to DeBraga \& Carroll (1993) being passed over in favour of Bell's (1993) study of mosasauroid interrelationships.

\section{Bell $(1993,1997)$}

Bell (1993) produced the most complete systematic analysis of mosasauroids to date (151 characters for 37 taxa) as a part of his $\mathrm{PhD}$ dissertation (this was pared down to 142 characters for 37 taxa by the time it was published (Bell, 1997) although the modifications did not change the preferred tree topology). Once again the focus of the analysis was not on aigialosaurs but instead on mosasaurs, but the analysis represented the first test of the monophyly of the Aigialosauridae (although it was not the first analysis to test this in press - the study was not published for four years (Bell, 1997; Fig. 2a) - it was chronologically the first to test the hypothesis). Bell (1993, 1997) did not include Carsosaurus marchesetti or any dolichosaurs, but did include 'the Dallas aigialosaur', now described as Dallasaurus turneri (Bell \& Polcyn, 2005). The results of the analysis showed aigialosaurs to be a paraphyletic group with Opetiosaurus being the sister taxon to all other mosasauroids and Aigialosaurus grouping with the basal mosasaur Halisaurus. These results were poorly supported by bootstrapping tests, but this may have been a result of large amounts of data missing from the aigialosaurian taxa. Bell $(1993,1997)$ represented the first rigorous test of the monophyly of the family Aigialosauridae since the erection of that taxon. It should also be noted that Bell (1993) did not find any support for a varanid/mosasauroids sister-group relationship, contradicting the findings of Carroll \& DeBraga (1992) and DeBraga \& Carroll (1993).

Bell $(1993,1997)$ included all mosasauroids with the exception of 0 . bucchichi in the family Mosasauridae on the basis of 
seven unequivocal characters. Two of these characters deal with the premaxilla and snout and a third characterises the width of the internarial process of the frontal. These areas are poorly preserved in A. dalmaticus and are absent from the Trieste specimen (A. Dutchak, pers. obs.). The split deltopectoral crest of the humerus with two insertion areas is listed as a character that unequivocally supports the family Mosasauridae (Bell, 1993) despite the fact that Dallasaurus is listed as showing the primitive characterisation of a single crest. Of the three remaining characters listed as giving unequivocal support to Bell's (1993) diagnosis of Mosasauridae, the midline dorsal keel of the frontal appears similar in Opetiosaurus and Aigialosaurus, although it is coded differently, and Opetiosaurus cannot be coded for either the presence or absence of zygosphenes and zygantra or the shape of the dorsal ridge of the vertebral synapophysis. However, despite several questionable character codings and a heavy bias in the matrix towards quadrate characters (20 of the 142 published in Bell, 1997), Bell $(1993,1997)$ was a good starting point for further investigations into mosasauroid interrelationships for later researchers.

\section{Caldwell et al. (1995)}

Bell's (1993) hypothesis of a paraphyletic Aigialosauridae was countered when Carsosaurus marchesetti was redescribed by Caldwell et al. (1995). While the focus of the paper was on limb mechanics and growth, aigialosaur systematics was also discussed, and the analysis (66 characters and ten taxa; Fig. 2b) represented the first published phylogenetic test of aigialosaur monophyly, two years prior to the publication of Bell's dissertation (Bell, 1997). The results of this test were less than spectacular, with Aigialosaurus, Opetiosaurus, Carsosaurus and the 'Trieste aigialosaur' nesting in a polytomy with the Mosasauridae (defined in this case as mosasauroids with paddlelike appendages). Caldwell et al. (1995) pointed out that the basal polytomy with mosasaurs was caused by a single character (relatively short ribs in the posterior portion of the rib cage) whereas the aigialosaurs were united (and differentiated from the mosasaurs) by eight characters including: an absence of contact between the postorbital and postfrontal, the presence of a premaxillary foramen, and the number of presacral vertebrae. This state of affairs indicated to Caldwell et al. (1995) that aigialosaurs probably represented a monophyletic assemblage. It should also be noted that, like Bell (1993), Caldwell et al. (1995) found no support for the varanid/mosasauroid sister group relationship recovered by Carroll \& DeBraga (1992) and DeBraga \& Carroll (1993).

\section{Caldwell (1996)}

With several different mosasauroid phylogenies available, Caldwell (1996) reviewed the hypotheses and published a data

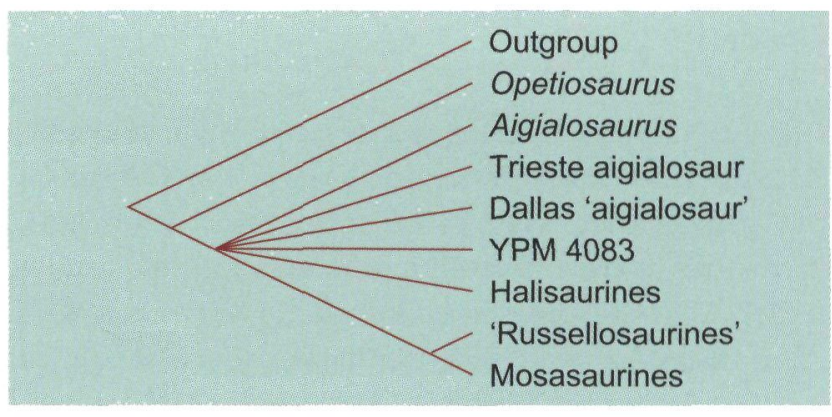

a.

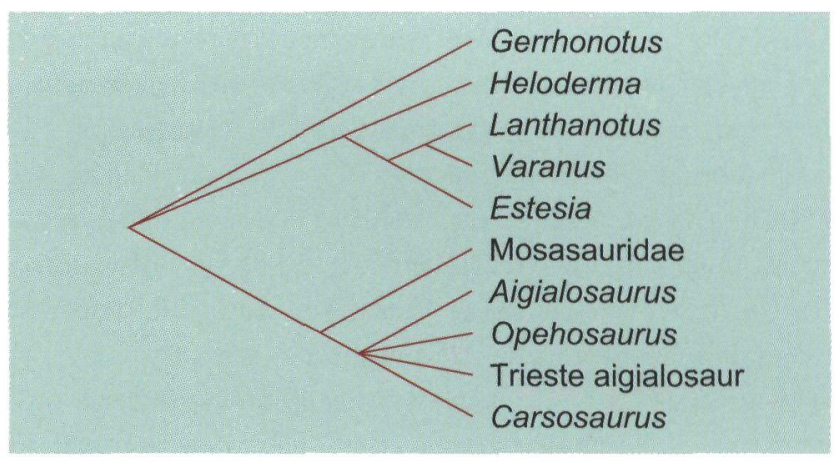

Fig. 2. a. The interrelationships of the mosasauroids, modified from Bell (1997) showing a paraphyletic Aigialosauridae; b. 50\% majority rule consensus tree from Caldwell (1995) showing a monophyletic Aigialosauridae.

set (91 characters and 15 taxa) constructed by taking Bell's (1993) matrix, removing a number of taxa and then deleting any characters that were phylogenetically uninformative for the remaining taxa. Caldwell (1996) did make some small adjustments to the character codings for 0 . bucchichi (which he considered congeneric with $A$. dalmaticus). In addition to these changes, Caldwell (1996) referred the "Trieste aigialosaur' (Carroll \& DeBraga 1992) to C. marchesetti and used the new specimen to fill in some gaps in the data set. The phylogeny recovered by Caldwell (1996) contradicted his earlier findings (Caldwell et al., 1995) by supporting a paraphyletic Aigialosauridae; hardly a surprise considering the characters were taken from Bell (1993).

\section{Caldwell (1999a)}

Caldwell (1999a) used a matrix that had been further pared down from Caldwell (1996) to examine coniasaur-mosasauroid relationships. Some of the 73 characters were reworded and the analysis included only 11 taxa (three of which were aigialosaurs) and once again a paraphyletic Aigialosauridae was recovered. As the matrix was still based on Bell's (1993) characters and codings, and no additional aigialosaur data were added, this result was to be expected. 


\section{Caldwell (2000)}

Caldwell (2000) published a further modification of the Bell (1993) matrix that recovered a monophyletic Aigialosauridae. This tree topology was a result of further changes to the matrix used in Caldwell's earlier publications (Caldwell, 1996, 1999a). Eight characters from Caldwell (1999a) were removed (these characters dealt with the fronto-parietal suture, the posterodorsal process of the maxilla, the shape of the scapulacoracoid suture and the composition of the appendicular epiphyses among other features) and a single character was added (the number of cervical vertebrae). The resulting matrix had 66 characters and twelve terminal taxa (with Dolichosaurus longicollis added to the taxa from Caldwell, 1999a). Only two characters supported a monophyletic Aigialosauridae to the exclusion of all other taxa: the lack of a constricted internarial process of the frontal and narrow pterygoid processes on the basisphenoid. These characters proved sufficient to maintain a monophyletic Aigialosauridae even when a strict consensus of the 27 most parsimonious cladograms was constructed. It should be noted that the cranial morphology of $C$. marchesetti is unknown so the strict consensus effectively supported the congeneric grouping of 0 . bucchichi and A. dalmaticus suggested by Caldwell et al. (1995).

\section{Bell \& Polcyn (2005) and Polcyn \& Bell (2005)}

The most recent analyses of the mosasauroid ingroup are found in the present volume (Bell \& Polcyn, 2005; Polcyn \& Bell, 2005). The systematic analysis in each publication is the same, with Bell (1997) being the source of all but two of the characters. This most recent analysis is the first to insert Haasiasaurus gittelmani, which was suggested to have aigialosaurian affinities (Polcyn et al., 1999). Not surprisingly, the tree topology recovered by Bell \& Polcyn (2005) is similar to that found in Bell (1997), although halisaurines were moved from the basal position to a sister group relationship (along with the 'Trieste aigialosaur') with russellosaurines. The major difference in the recent study is that the basal polytomy has been resolved. Opetiosaurus and Aigialosaurus are found to be sequential sister taxa to the rest of the mosasauroids whereas Haasiasaurus is found to be the sister taxon to the clade of (halisaurines (russellosaurines)), the 'Trieste aigialosaur' is the sister taxon to halisaurines and Dallasaurus (still referred to as 'the Dallas aigialosaur' in the data matrix) is the sister taxon to mosasaurines.

Because the purpose of their studies was to analyse the relationships of mosasaur taxa in detail, the authors (Bell \& Polcyn, 2005; Polcyn \& Bell, 2005) may be excused for not reducing the number of taxa used in the matrix. However, if the goal of the study is to examine relationships between taxa, then only diagnosable taxa should be included. One cannot make an informative statement about the relationship of any taxon to 'Taxon novum YMP' (Polcyn \& Bell, 2005) if this specimen lacks diagnosable characters. In addition to the presence of several superfluous taxa, the authors do not explain why the character scoring changes for aigialosaurian taxa suggested by Caldwell (1996) have not been added or addressed in the text.

Bell \& Polcyn (2005) argue that paddle-like limbs may have evolved twice or more (judging from their tree one would suggest three times) in mosasauroids. This implies that paddles cannot be used as a plesiomorphic character uniting mosasaurs. Instead, the plesiomorphies uniting all aigialosaurs and mosasaurs would be features of the skull as found in Aigialosaurus dalmaticus and Opetiosaurus bucchichi. These features, which are clearly plesiomorphic for the entire ingroup of Bell \& Polcyn (2005), might include quadrate morphology, dental morphology and that of the intramandibular joint. Following this reasoning, it is not aigialosaurs that are subsumed within the Mosasauridae, but rather that all mosasauroids are subsumed within the Aigialosauridae, leaving the Mosasauridae as a polyphyletic taxon. Mosasaurs are nothing more than aigialosaurs that evolved paddle-like limbs at least three times in their history. Bell \& Polcyn's (2005) phylogeny supports the monophyly of traditional mosasauroid subfamilies, e.g., Halisaurinae, Russellosaurinae and Mosasaurinae (although the families have been rearranged), but finds no support for a paddle-bearing common ancestor, distinct from an aigialosaur, that was by diagnosis of possession of paddles plus 'aigialosaur' cranial characters, a mosasaur. This is an important perspective that influences the interpretation of phylogenetic results that is not discussed by Bell \& Polcyn (2005) nor by Polcyn \& Bell (2005).

Bell \& Polcyn's (2005) phylogeny provides two nomenclatural possibilities for re-naming the clearly polyphyletic Mosasauridae. The difference depends on the naming convention applied. For Node-Based taxonomy: Aigialosauridae is monophyletic inclusive of all descendant taxa, and the name Mosasauridae should be discarded in favour of Aigialosauridae with descendant clades bearing new names at the respective nodes. For Stem-Based taxonomy: a new name, Aigialosauroidea, inclusive of the most recent common ancestor of Opetiosaurus bucchichi (the most basal mosasauroid in the phylogeny) and all of its descendants, and the Mosasauridae inclusive of the most recent common ancestor of (Haasiasaurus + ((the 'Trieste aigialosaur' + Halisaurus) + Russellosaurinae)) and (Dallasaurus + Mosasaurinae).

\section{Global analyses including aigialosaurs}

While the series of mosasauroid ingroup analyses failed to yield a definite answer as to the monophyly or paraphyly of the Aigialosauridae, several larger-scale squamate analyses were undertaken to investigate the relationships of various taxa within Squamata (Lee, 1997; Caldwell, 1999b; Lee \& 
Caldwell, 2000; Lee \& Scanlon, 2002; Pierce \& Caldwell, 2004). In no case were aigialosaurs the focus of these studies, but the results are nonetheless informative.

\section{Lee (1997)}

Lee (1997) used previous studies of squamate systematics (Pregill et al., 1986; Estes et al., 1988; Rieppel, 1988; DeBraga \& Carroll, 1993) to construct a data matrix of 144 osteological characters for 15 terminal taxa. The study focused on the relationships within Platynota and, unlike previous studies, included numerous fossil taxa (10 of the 15 taxa). The results of the systematic analysis indicated strong support (40 characters and a bootstrap score of 100) for a pythonomorph clade of mosasauroids and snakes. Lee (1997) determined that varanids were the sister group to pythonomorphs. While this placement appears to contradict Carroll \& DeBraga's (1992) and DeBraga \& Carroll's (1993) suggestion that mosasauroids were the sister taxon to varanids, snakes were not included in either of the earlier studies so the pythonomorph clade could not be tested.

\section{Lee (1998)}

Lee (1998) (Fig. 3a) built upon his previous study (Lee, 1997) and produced a much larger data set (230 osteological characters for 22 taxa) including all squamate groups. Once again, when mosasauroids were included in the matrix they formed a wellsupported pythonomorph clade with snakes. The mosasauroidsnake relationship is supported by 43 characters (about 30 of which deal with the braincase, tooth replacement and the mandible and intramandibular hinge), most of which are diagnosable only on mosasaurian taxa.

\section{Caldwell (1999b)}

Caldwell (1999b) (Fig. 3b) also determined that the varanoid relationships of mosasauroids proposed by Carroll \& DeBraga (1992) were not supported (based on 95 osteological characters and 21 terminal taxa), and that mosasauroids together with coniasaurs formed the sister group to snakes (Fig. 6). Caldwell's (1999b) study was also based upon the previous work of Estes et al. (1988) with the differences being the addition of fossil taxa to the matrix and the removal of softtissue characters. The (Mosauroidea, Coniasaurus) Serpentes) clade was supported by five unequivocal and four equivocal characters. The majority of these characters deal with the intramandibular hinge, although the presence of zygosphenes and zygantra also supports the clade. The clade of mosasauroids, coniasaurs and snakes was found to be the sister group to Scleroglossa (all other squamates except iguanians).

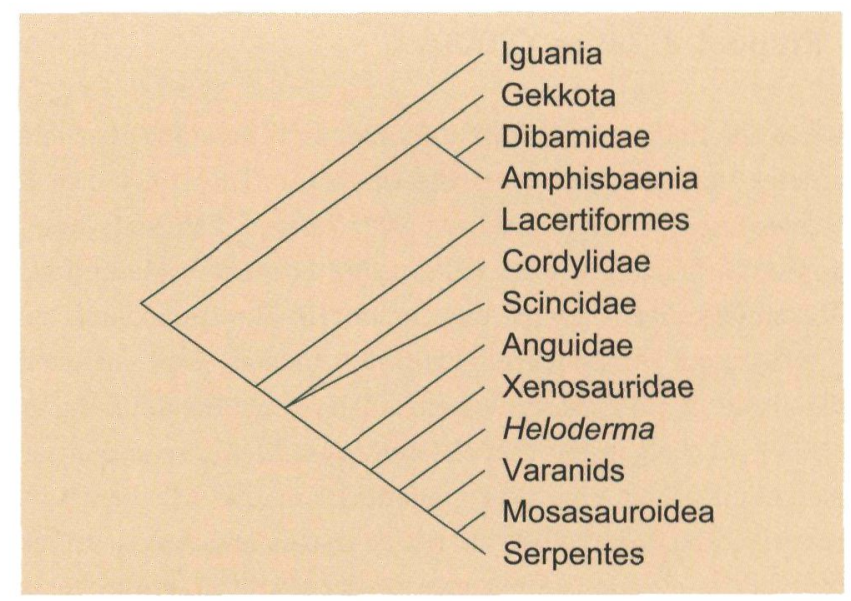

a.

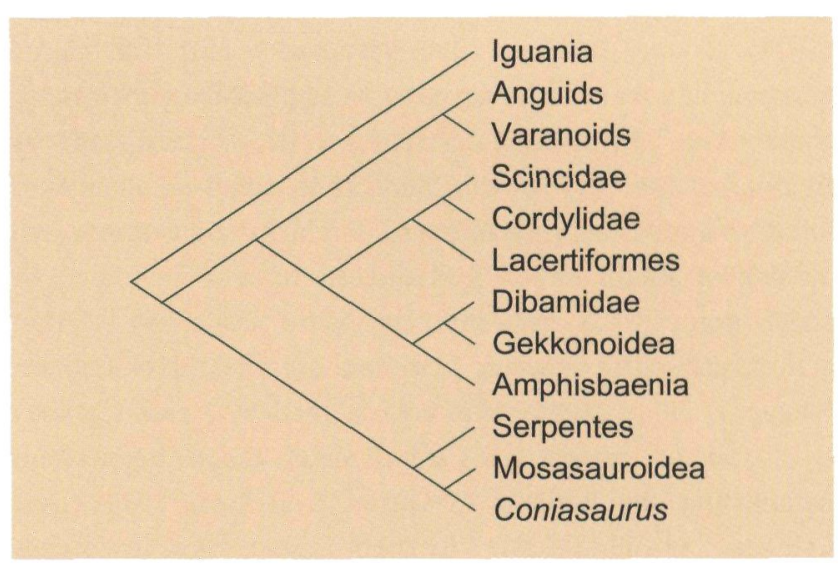

b.

Fig. 3. a. The systematic relationships of squamates, modified from Lee (1998) showing mosasauroids as the sister group to Serpentes; $b$. squamate relationships modified from a majority rule consensus tree (Caldwell, 1999b) showing mosasauroids and coniasaurs as the sister group to Serpentes.

\section{Lee \& Caldwell (2000)}

Lee \& Caldwell (2000) again recovered a well-resolved Pythonomorpha, this time using a modified version of Lee's (1998) data matrix. Lee \& Caldwell (2000) used 258 characters coded for 32 terminal taxa. This matrix was further modified by Lee $\&$ Scanlon (2002), who reduced the number of characters (248) and added Mesoleptos zendrinii, the focal point of the paper. A third study (Pierce \& Caldwell, 2004) reduced Lee \& Caldwell's data set to 15 anguimorph taxa and coded them for 159 characters (the reasons for the reduction in characters are not explicitly stated but it can be assumed that the change is due at least in part to the reduction of terminal taxa that made many characters autapomorphic and uninformative). Pierce \& Caldwell (2004) focused on the relationships of the dolichosaur Pontosaurus lesinensis within anguimorphs and thus paid little attention to the placement of the mosasauroids clade other than to note that it fell out as the sister group to the dolichosaur-snake assemblage (thereby retrieving a monophyletic Pythonomorpha). 


\section{Rieppel \& Zaher (2000)}

While the findings of Caldwell (1999b) and Lee (1997) and the studies that stemmed from that data set (Lee, 1998; Lee \& Caldwell, 2000; Lee \& Scanlon, 2002; Pierce \& Caldwell, 2004) appear to indicate a solid relationship between mosasauroids and snakes, not everyone was convinced. The findings of Lee (1998) (and consequently all the studies that utilized variations of this matrix) were challenged by Rieppel \& Zaher (2000), who suggested that the dentition, braincase and intramandibular joint characters (about 30 of the 43 characters suggested by Lee (1998)) that link snakes and mosasauroids together as pythonomorphs may be the result of convergence. By modifying the character set and ingroup taxa from Lee (1998), Rieppel \& Zaher (2000) retrieved results that placed mosasauroids as the sister group to an amphisbaenian/dibamid/ snake clade within Anguimorpha, which contradicted the findings of Lee (1998), who found that, when all squamates are tested together, dibamids and amphisbaenians group well outside of Anguimorpha and instead form a monophyletic sister group to a gekkonid/pygopodid clade. By further manipulating the ingroup taxa and ordering of characters, Rieppel \& Zaher (2000) were able to retrieve a tree topology that grouped mosasauroids as a sister taxon to varanids (supporting the findings of Carroll \& DeBraga (1992) and DeBraga \& Carroll (1993)). This hypothesis requires acceptance that amphisbaenians and dibamids are nested within Angiumorpha, a relationship that requires further investigation. The numerous modifications to character scoring, weighting, and ordering by Rieppel \& Zaher (2000) serve as an excellent reminder that selective manipulation of ingroup taxa and characters can allow a researcher to obtain almost any tree topology.

\section{Conclusions}

The monophyly of the aigialosaurs is again being questioned (Bell \& Polcyn, 2005; Polcyn \& Bell, 2005), though what is clear now is that this is a matter of taxonomic definition. Cleary, redescriptions of the key taxa (Aigialosaurus dalmaticus, Opetiosaurus bucchichi and 'the Trieste aigialosaur') are essential to further investigations into re-testing the most recent hypotheses. Bell's (1993) data matrix has proven to be the most popular tool for hypothesising mosasauroid phylogenies and the many modifications to the characters and taxa included in the matrix have resulted in a very robust data set. While the most streamlined versions of Bell's (1993) matrix (Caldwell, 1999a, 2000) may not be optimal for testing relationships within Mosasauridae it is essential that the modifications to character scoring among the basal taxa be utilised or discussed by later researchers so as to continue improving the understanding of mosasauroid systematics. The next step in this process is to insert the information gained from redescriptions of Opetiosaurus bucchichi and Aigialosaurus dalmaticus and the description of the "Trieste aigialosaur' alongside the data from Dallasaurus and Haasiasaurus to get the most inclusive hypothesis of mosasauroid interrelationships to date.

The question of where mosasauroids fit within Squamata remains a hotly debated topic, with all of the recent analyses tracing their roots back to Estes et al. (1988). The close relationship of mosasauroids with snakes remains uncertain, but the sister group relationship between varanoids and mosasauroids has been poorly supported in most recent studies. Lee's (1998) matrix will continue to provide a source of informative characters and is a good starting point for future studies. The problems inherent in squamate systematics stem in large part from a lack of fossil data for numerous groups (not the least of which are amphisbaenians and dibamids). Until this problem is rectified it is unlikely that squamate relationships will be distilled to a single robust hypothesis.

\section{Acknowledgements}

The author would like to thank Dr. M. Caldwell for his guidance and candid discussions on many topics, K. Smith and M. Polcyn for their helpful reviews of the manuscript, A.S. Schulp and Dr. J.W.M. Jagt and the Natuurhistorisch Museum Maastricht for organising the First Mosasaur Meeting, the members of the UALVP for many helpful discussions and the many workers that have contributed to the understanding of aigialosaurs and mosasaurs. Information for this paper was gathered in part thanks to University of Alberta GSA and FGSR travel funds.

\section{References}

Bell, G.L. Jr., 1993. A phylogenetic revision of the Mosasauroidea (Squamata). Ph.D. dissertation, University of Texas, Austin, Texas: 1-293.

Bell, G.L. Jr., 1997. A phylogenetic revision of North American and Adriatic Mosasauroidea. In: J.M. Callaway and E.L. Nicholls (eds): Ancient Marine Reptiles. Academic Press (San Diego): 281-332.

Bell, G.L. Jr. \& Polcyn, M.J., 2005. Dallasaurus turneri, a new primitive mosasauroid from the Middle Turonian of Texas and comments on the phylogeny of Mosasauridae (Squamata). In: Schulp, A.S. \& Jagt, J.W.M. (eds): Proceedings of the First Mosasaur Meeting. Netherlands Journal of Geosciences 84: 177-194.

Caldwell, M.W., Carroll, R.L. \& Kaiser, H., 1995. The pectoral girdle and forelimb of Carsosaurus marchesetti (Aigialosauridae), with a preliminary phylogenetic analysis of mosasauroids and varanoids. Journal of Vertebrate Paleontology 15: 516-531.

Caldwell, M.W., 1996. Ontogeny and phylogeny of the mesopodial skeleton in mosasauroids reptiles. Zoological Journal of the Linnean Society 116: 407-436.

Caldwell, M.W., 1999a. Description and phylogenetic relationships of a new species of Coniasaurus Owen, 1850 (Squamata). Journal of Vertebrate Paleontology 19: 438-455. 
Caldwell, M.W., 1999b. Squamate phylogeny and the relationships of snakes and mosasauroids. Zoological Journal of the Linnean Society 125: 115-147.

Caldwell, M.W., 2000. On the aquatic squamate Dolichosaurus longicollis Owen, 1850 (Cenomanian, Upper Cretaceous), and the evolution of elongate necks in squamates. Journal of Vertebrate Paleontology 20: 720-735.

Calligaris, $R$., 1988. I rettili fossili degli 'Strati calcariei ittilitici di comeno' e dell'isola di lesina. Atti del Museo Civico di Storia naturale Trieste 41: 85-125.

Camp, C.L., 1923. Classification of the lizard families. Bulletin of the American Museum of Natural History 48: 289-481.

Camp, C.L. \& Allison, H.J., 1961. Bibliography of fossil vertebrates 1949-1953. Memoirs of the Geological Society of America 84: 1-532.

Carroll, R.L. \& DeBraga, M., 1992. Aigialosaurs: mid-Cretaceous varanoid lizards. Journal of Vertebrate Paleontology 12: 66-86.

DeBraga, M. \& Carroll, R.L., 1993. The origin of mosasaurs as a model of macroevolutionary patterns and processes. Evolutionary Biology 27: 245-322.

Dollo, L., 1904. L'origine des mosasauriens. Bulletin de la Société belge de Geologie, de Paléontologie et d'Hydrologie 18: 217-222.

Estes, R., de Quieroz, K. \& Gauthier, J., 1988. Phylogenetic relationships within Squamata. In: Estes, R. \& Pregill, G. (eds): Phylogenetic Relationships of the Lizard Families. Stanford University Press (Stanford): 119-281.

Féjérváry, G.J., 1918. Contributions to a monograph on fossil Varanidae and on Megalanidae. Annals of the National Museum of Hungary 16: 341-467.

Hennig, W., 1966. Phylogenetic Systematics. University of Illinois Press (Chicago): $263 \mathrm{pp}$.

Kornhuber, A.G., 1873. Über einen neuen fossilen Saurier aus Lesina. Abhandlungen der kaiserlich-königlichen geologischen Reichsanstalt zu Wien 5: 75-90.

Kornhuber, A.G., 1893. Carsosaurus Marchesettii, ein neuer fossiler Lacertilier aus den Kreideschichten des Karstes bei Komen. Abhandlungen der kaiserlich-königlichen geologischen Reichsanstalt zu Wien 17(3): 1-15.

Kornhuber, A.G., 1901. Opetiosaurus Bucchichi, eine neue fossile Eidechse aus der unteren Kreide von Lesina in Dalmatien. Abhandlungen der kaiserlichköniglichen geologischen Reichsanstalt zu Wien 17(5): 1-24.

Kramberger, K.G., 1892. Aigialosaurus, eine neue Eidechse aus den Kreideschiefern der Insel Lesina mit Rücksicht auf die bereits beschriebenen Lacertiden von Comen und Lesina. Glasnik huvatskoga naravolosovnoga derstva (Societas historico-matulis croatica) u Zagrebu 7: 74-106.

Kuhn, O., 1958. Ein neuer Lacertilier aus dem fränkischen Lithographieschiefer. Neues Jahrbuch für Geologie und Paläontologie, Monatshefte 1958: 475-510.

Lee, M.S.Y., 1997. The phylogeny of varanoid lizards and the affinities of snakes. Philosophical Transactions of the Royal Society, London: B 352: 53-91.

Lee, M.S.Y., 1998. Convergent evolution and character correlation in burrowing reptiles: towards a resolution of squamate relationships. Biological Journal of the Linnean Society 65: 369-453.

Lee, M.S.Y. \& Caldwell, M.W., 2000. Adriosaurus and the affinities of mosasaurs, dolichosaurs, and snakes. Journal of Paleontology 74: 915-937.

Lee, M.S.Y. \& Scanlon, J.D., 2002. The Cretaceous marine squamate Mesoleptos and the origin of snakes. Bulletin of the Natural History Museum of London, Geology 68: 131-142.

McDowell, S.D. \& Bogert, C.M., 1954. The systematic position of Lanthanotus and the affinities of the anguimorph lizards. Bulletin of the American Museum of Natural History 105: 1-142.
Von Meyer, H., 1860. Acteosaurus tommasinii aus dem schwarzen Kredeschiefern von Comen am Karste. Palaeontgraphica 7: 223-231.

Nopcsa, F., 1903. Über die varanusartigen Lacerten Istriens. Beiträge zur Paläontologie und Geologie Österreich-Ungarns und des Orients 15: 31-42.

Nopcsa, F., 1908. Zur Kenntnis der fossilen Eidechsen. Beiträge zur Paläontologie und Geologie Österreich-Ungarns und des Orients 21: 33-62.

Nopcsa, F., 1923. Eidolosaurus und Pachyophis: zwei neue Neocom-Reptilien. Palaeontographica 65: 96-154.

Owen, R., 1850. Description of the fossil reptiles of the Chalk Formation. In: Dixon, F. (ed.): The Geology and Fossils of the Tertiary and Cretaceous Formations of Sussex. Longman, Brown, Green and Longman (London): 378404.

Pierce, S.E. \& Caldwell, M.W., 2004. Redescription and phylogenetic position of the Adriatic (Upper Cretaceous; Cenomanian) dolichosaur Pontosaurus lesinensis (Kornhuber, 1873). Journal of Vertebrate Paleontology 24: 373-386.

Polcyn, M.J. \&Bell, G.L., 2005. Russellosaurus coheni n. gen., n. sp., a 92 million-year-old mosasaur from Texas (USA), and the definition of the parafamily Russellosaurina. In: Schulp, A.S. \& Jagt, J.W.M. (eds): Proceedings of the First Mosasaur Meeting. Netherlands Journal of Geosciences 84: 321-333.

Polcyn, M.J., Tchernov, E., \& Jacobs, L.L., 1999. The Cretaceous biogeography of the Eastern Mediterranean with a description of a new basal mosasauroid from the 'Ein Yabrud, Israel. In: Tomida, Y., Rich, T. H., \& Vickers-Rich, P. (eds): Proceedings of the Second Gondwanan Dinosaur Symposium, National Science Museum Monogaphs, No. 15: 259-290.

Pregill, G.K., Gauthier, J.A. \& Greene, H.W., 1986. The evolution of helodermatid squamates, with description of a new taxon and an overview of Varanoidea. Transactions of the San Diego Society of Natural History 21: 167-202.

Rieppel, O., 1988. A review of the origin of snakes. Evolutionary Biology 22: 37-130.

Rieppel, O. \& Zaher, H., 2000. The intramandibular joint in squamates, and the phylogenetic relationships of the fossil snake Pachyrachis problematicus Haas. Fieldiana (Geology), New Series 43: 1-69.

Russell, D.A., 1967. Systematics and morphology of American mosasaurs. Peabody Museum of Natural History, Yale University, Bulletin 23: 1-241.

Seeley, H.G., 1881. On remains of a small lizard from Neocomian rocks of Comen, near Trieste, preserved in the Geological Museum of the University of Vienna. Quarterly Journal of the Geological Society of London 37: 52-56.

Williston, S.W., 1904. The relationships and habits of the mosasaurs. Journal of Geology 12: 43-51. 